\title{
Education Reorientation System in the Future
}

\author{
Uli Anto Hutagalung ${ }^{1 *}$, Paningkat Siburian ${ }^{2}$ \\ 1)Post Graduate Education Management Universitas Negeri Medan, Indonesia \\ 2)Professor at Universitas Negeri Medan, Indonesia \\ *hutagalung.ulianto123gmail.com
}

\begin{abstract}
The purpose of this research is to find out the nature of education in the future which is a process of empowerment that frees individuals from the confines of a centralized power structure, which is able to build a power structure that only benefits a small group of people that afflicts the people. Therefore, the desire to continue to maintain pedagogic within a narrow paradigm must be reviewed, and as soon as possible a change of orientation is made toward a critical pedagogic or pedagogical empowerment. Critical pedagogic is an engineering of thought that seeks to perfect pedagogic that we have known as pedagogic in a narrow paradigm, namely pedagogic which tends to see educational problems merely as technical problems in the classroom. Though education is not merely learning, but education is also closely related to all aspects of human life in the community. Education becomes a process of hominization and humanization of a person in the life of families and communities that are cultured now and in the future. Therefore, this paradigm shift certainly requires the repositioning of educators and students in a better education and learning process.
\end{abstract}

Keywords: reorientation; empowerment; pedagogic; education

\section{Introduction}

Changes in the direction of education is leading to changes in behavior which itself requires strong time and effort. Education is an aspect of culture that is not easy to change as culture itself is difficult to change in the blink of an eye. Therefore, changes in education must be gradual by taking into account the various potentials, weaknesses, strengths, and possibilities that are open. Thus the change in education requires planning and adequate preparation and is supported by adequate resources including political commitment of the community. The direction of education must be changed with reference to the factors of the development of science, technology and globalization. Today we cannot avoid globalization which enters all aspects of human life, therefore it is necessary to strive for education that builds the character of students who have a strong sense of nationality, have good behavior, and are able to master science and technology, so they can compete in national and international scene. In developing a new Indonesian society, critical issues of education faced by the Indonesian people and nation in the medium term include the following:
a. Education that develops democratic values;
b. Development of human rights;
c. Eradication of poverty;
d. Implementation of regional autonomy in the fields of education and culture. 
According to [1] noted that the success of a student depends on 21 st century skills, so students must learn to have it. Partnership for 21st Century Skills identifies 21st Century skills including:

a. Thinking critically, means students are able to respond to knowledge and knowledge critically, able to utilize it for humanity.

b. Problem solving, being able to solve a problem means being able to overcome the problems it faces in the process of learning activities as a vehicle for training to face greater problems in his life.

c. Communication and collaboration.

d. Communication skills refer to the ability to identify, access, utilize and optimize communication tools and techniques to receive and convey information to other parties.

e. Skilled collaboration means being able to collaborate with other parties to improve synergy.

While according to the National Education Association to achieve success and be able to compete in a global society, students must be experts and have skills as communicators, creators, critical thinkers, and collaborators. At present learning in schools needs to be prepared and prepare for the challenges of the 21 st century. Understanding of 21 st century skills is important to convey to students. Achieving 21st century skills is done by understanding the characteristics, achievement techniques and learning strategies undertaken.

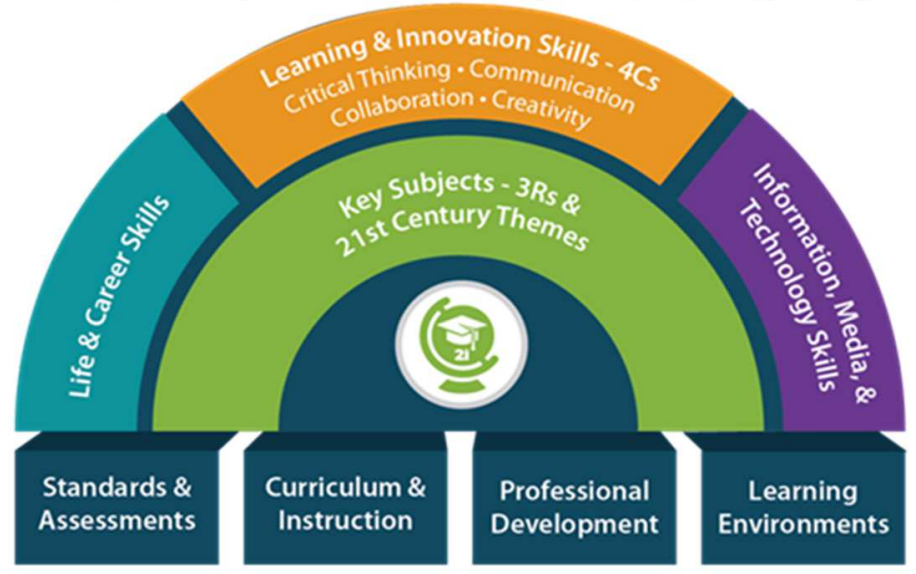

Figure 1. Learning Characteristics on $21^{\text {st }}$ century

In order for an educator to build 21st century learning skills, you need to know the challenges of 21 st century learning. The challenges of teachers in the 21 st Century according to [2] there are four traits that emerged in the 21 st century that affect human life and civilization, namely:

a. That there will be major changes in almost all areas of life, and that these changes will take place increasingly acceleration.

b. That the role of science and technology will take a central position which directly influences not only the daily lifestyle of humans, but also influences the values of art, morals and religion.

c. That the struggle and competition for life between nations will not be limited to the economic sector, but also in various other fields, including culture and ideology. 
d. That because of the influence of science and technology, moral and religious values will be immediately uprooted and it is not impossible that it will cause a different value system from what is known to date. Along with the central role of science and technology, the development of science and technology-based industries will develop rapidly.

The 21st Century Learning is learning that integrates literacy skills, knowledge skills, skills and attitudes, and mastery of technology. Literacy is the most important part in an educational process, students who can carry out literacy activities with a maximum course will get more learning experience compared to other students. 21 st Century education is education that integrates knowledge skills, skills and attitudes, as well as mastery of ICT. These skills can be developed through various models of activity-based learning in accordance with the characteristics of competencies and learning materials. The skills needed in the 21 st Century are also higher order thinking skills (HOTS) that are very much needed in preparing students to face global challenges.

According to [3] author that to be able to develop 21st century learning there are several important things to note, including: (a) The main task of the teacher as a Learning Planner and facilitator and class manager, the important task of the teacher is in making lesson plans. (2) The lesson plan must be good and detailed and be able to explain all the processes that will occur in the class including the assessment process and the targets to be achieved. In preparing lesson plans, teachers must be able to combine the targets required in the national curriculum, the development of 21 st century skills or national character and the use of technology in the classroom.

\section{Enter the elements of Higher Order Thinking.}

Technology in this case, especially the internet will greatly facilitate students to obtain information and answers to problems raised by the teacher. For problems that are knowledge and understanding solutions can be found very easily and there is a tendency that students only become information gatherers. Teachers must be able to provide assignments at the application, analysis, evaluation and creative levels, this will encourage students to think critically and read the information they have collected before completing the assignment from the teacher.

Application of varied learning approaches and models Some learning approaches such as Project Based Learning, Inquiry Based Learning and Jigsaw and Flipped Classroom models can be applied by teachers to enrich the learning experience of students (Learning Experience). One thing that needs to be understood is that students must understand and understand the relationship between the knowledge learned in school and real life, students must be able to apply their knowledge to find solutions to problems in real life.

Technology Integration. Schools where students and teachers have good technology access must be able to utilize technology in the learning process, students must be accustomed to working with technology like people who work. Teachers often complain about technological facilities that they do not yet have, one thing is that the development of learning in the 21 st century can be done without technological elements, the most important thing is that good teachers can develop an active and collaborative learning process, but of course teachers must try to master the technology first. The most basic thing to remember is that technology will not be a good and powerful tool if the learning patterns are still traditional. 


\section{Research Method}

This research uses a qualitative approach; narrative descriptive. The data was taken from various educational literature / documents, observations and interviews with the teachers in South Tapanuli Regency North Sumatra in 2018. The data analysis technique used was inductive data analysis.

\section{Results and Discussion}

In developing democratic values through education, these values must be animating in all educational activities including the system, curriculum, and methodology used. Indoctrinated educational practices are not in accordance with these objectives, also the curriculum is very centralistic and kills individual potential. Teaching and learning processes that kill student's initiative and creative thinking are no longer in place. Education means a process of humanization; therefore, it is necessary to respect human rights. Students are not robots but humans who must be assisted in the process of maturity so that he can be independent and think critically. Besides education is a human right, therefore education equality must be carried out consistently. Equitable education is related to poverty, and therefore poverty is a priority that needs to be addressed in line with the implementation of equity itself. That education, which is essentially a process of empowerment that is freeing individuals from the confines of a centralized power structure, which trampled on human rights, which built a power structure that only benefits a small group of people that afflicts the people. The liberation pedagogic is a pedagogic that empowers students to build a new Indonesian society.

\section{From Pedagogic Narrow to Critical Pedagogic}

Critical pedagogic is an engineering of thought that seeks to perfect pedagogic as we know it as a pedagogic in the narrow paradigm or black pedagogic in Kurt Singer's terms, a pedagogic that tends to see educational problems merely as technical problems in the classroom. Though education is not merely learning, but education is also closely related to all aspects of human life in society. Education is not just about making students good at memorizing, but more importantly is making it as a human being, or in the term Driyakarya, education is a process of humanizing humans. Education is the process of hominization and the process of humanization of a person in family life, civilized society now and the future [4]. With this formulation, a narrow view of education will be difficult to function in building a new democratic and moral Indonesian society.

In its development, pedagogical schools can be identified into five major schools. These streams have their own views about the present and future of the desired community. First, the flow of functionalism with the characters Durkheim and Parsons. According to this flow, the function of education today is the transmission of culture and maintaining the existing social order. Its future is prepared by teaching functions in future society. Second, the flow of culturalism with its leaders Brameld and Ki Hajar Dewantara [5], sees the function of education today as an effort to reconstruct society. Society has problems faced and educational efforts are to overcome these problems such as national identity, cultural clash, preservation and cultural development. The function of education is to organize society based on universal cultural functions based on local culture that is developing towards national culture and global culture such as the Trikon theory from Ki Hadjar Dewantara. 
Third, critical flow with the figures Marx, Bowless, Freire, Gyroux, Vygotsky. For the critical flow which is divided into adherents of conflict theories such as Marx, Bowels, also those who embrace critical theories such as Freire, Gyroux, and Vygotsky. The present function of education is seen as a reproduction of the current economic order. As for Freire, Gyroux, and Vygotsky the function of education is to empower the oppressed. The future development of society for critical pedagogics is emphasized in fostering economic equality and class struggle journals such as Marx, or developing critical literacy for many people. Fourth, interpretive flow with the character Bernstein. According to this flow the task of education is to teach various roles in society through programs in the curriculum. As for the future of education, it serves to eliminate various cultural biases and social classes that distinguish between the elite and the poor who are poor. Fifth, the post-modern genre with its figures Derrida, Faoucault and Gramsci. This flow is very popular and the thoughts of Derrida, Fsoucault and Gramsci are quite extreme to dominate this school. According to this flow, the function of education is to foster individuals who are free to formulate opinions and express their own opinions in various perspectives. Desired individuals are creative individuals and think including productive thinking freely.

The critical pedagogical schools above have a similarity in the discussion, namely individual empowerment. This is the essence of democratic society. Certainly the critical pedagogical schools above have limitations. As reminded by [6] freedom or individual autonomy is not unlimited autonomy but autonomy in the balance and social order related to the recognition of core values that are recognized together. The function of education in new Indonesian society is not education that fosters egoistic individualism, but individuals who develop their potential so that they can contribute as much as possible to the common good. That is the individual who lives in Indonesian civil society, who has an identity as an Indonesian as well as a man who lives peacefully with fellow human beings on this planet. By itself education for world peace is one of the agendas in education to build a new Indonesia society, namely Indonesian civil society.

\section{Orientation to Educators}

Teaching is a word that greatly influences the success of an educational process, teaching is also the one that gets scathing criticism from Paulo Freire with a passive learning model, namely educators explain, students listen, educators dictate, learners take notes, educators ask questions, learners answer, and students respond so on. This fact is termed Paulo Freire as a banking-style education (banking system), namely the education of deposit models, educators as depositors who deposit their knowledge and various experiences to students, while students only accept, record and store all information conveyed by educators. Bank style education is a model of oppression of students, because it inhibits the creativity and potential development of students [7].

Learning the model above, by [6] sometimes referred to as command style education, which develops the principle of distribution of a decision must be done hierarchically, from top to bottom, from teacher / educator to students ([8] in command style learning, all planning is determined by the teacher / educator, delivered to students, and students receive new lessons. However, they are not involved in the analysis process to apply the new experience to other life contexts, and furthermore, they are also not involved in the discussion of feedback for teachers / educators. Command style learning is one of the final forms of polarization of behaviorism, which then gets criticized for killing the spirit of democratization and killing the creativity of students, not respecting students, and not appreciating the diversity of students [9]. In connection with the above, then the task style model is developed, namely learning by 
increasing the assignment, which is then followed by the reciprocal style model, namely learning between the assignment and instructional models, and followed by the emergence of various models such as collaborative and cooperative learning developed by psychology flow. developmental, which emphasizes student activity and is assisted by teachers or educators.

In the context of this flow it is clear that the position of the teacher or educator in a learning process is no longer the center or source of all sources, but rather is positioned as a partner in charge of helping and facilitating student learning. Regarding the position of the teacher or educator in a learning process does have a long enough historical journey to follow the development of thought that gave birth to theories about learning. Repositioning the position of the teacher or educator in a learning process changes with the shifting definitions and paradigms of learning and learning. At the beginning of the second half of the 20th century, teaching was still interpreted as a process of providing guidance and advancing learner learners which were all done centered on learners [10]. The pedagogical view above has actually developed towards an educational model that is centered on students, only the involvement and educators in the learning process is still very large. These are the parts which were then widely criticized by educational scientists in the late 20th century, by giving students as much opportunities as possible to learn.

Quoted from [10] article that, the role of the teacher as a student is very beneficial for him, especially for students. When teaching, the teacher gets a lot of input, both from the subject matter being taught as well as from topics related to it. As a student, a teacher should not be easily satisfied. One of the most important factors in teaching is the feeling of being dissatisfied with the skills and knowledge that are constantly held. A teacher must have the desire to try to achieve even higher skills. That way, to improve the professionalism of teachers, he must continuously learn. There are other benefits that students will receive from dynamic and developing teachers because they enjoy learning. They will always get fresh new things because the teacher also always presents new things that he gets. Thus, students automatically will also be more developed because the input obtained is not an old item, but a new and fresh one. In order for teaching to be very dynamic, a developing teacher should always look for suggestions to maintain or even increase the excitement that is being felt.

The best way for the teacher is to always learn again and combine the new lesson with the old knowledge he has taught. Thus the material taught will always follow developments. There are several ways that can help and support the teacher's role as a student. Efforts that can be made are conducting research on the subject being taught. This research can be done when preparing lessons. In preparation, he can collect data from textbooks supporting teaching guidelines. Research can also be done from books outside of supporting books.

From research on sources outside the lessons he teaches, he can see the relationship between his subjects with other knowledge so he needs to find and research other knowledge, which of course will greatly support the progress of his profession. Observation of events around can also be a new source for subjects taught by a teacher. The events or events he observes can be illustrative material that can clarify students' understanding of the lesson so that it raises their interest in learning. Even further, students can connect the events or daily events around them with the lessons they receive. Another larger activity is Classroom Action Research (CAR). With CAR, the teacher can overcome and improve learning problems that are specific and specific to certain subjects.

There are other efforts that can help and support the teacher's role as a student, namely by attending school again. To increase knowledge, teachers can attend higher level schools. He can also attend seminars related to his profession as a teacher. This will open up the horizons of thinking and broaden his understanding because in this place he will meet people who have 
the same or different experiences and problems. Different experiences will enrich the teacher. Maybe this effort is a bit difficult to implement, but this way will greatly support the teaching profession. Successful instructors require diligent investigation and careful preparation of each lesson. From there it is known that preparation carefully thought out is the key to better teaching. Therefore, the teacher who makes the best possible preparation will get the most results. Thus teachers who are willing to work hard, master well in each lesson, will enjoy greater satisfaction in their work.

From some of the views on learning above, the latest definitions of teaching and learning are already very student-based, the teacher / educator only takes a role in the design to provide opportunities for learners to develop learning activities, and explore new experiences to achieve various idealized competencies, and has become joint class agreements with the teacher or educator. Along with these developments and advances, it seems that the paradigm of behaviorism has begun to be criticized with the development of constructivism flow as a flow of cognitive psychology [7]. Behaviorist views that learning is changing the behavior of students from not being able to, from not understanding to understanding, and the task of the teacher / educator is to control the stimulus and learning environment so that the change approaches the desired goal, and the teacher gives the gift or punishment to students, that is, prizes are given to students who have been able to show meaningful changes, while punishment is given to students who have not shown significant changes. Therefore, the flow of behaviorism puts the process of reinforcement in a very important position for students to achieve the desired changes. While the cognitive psychology stream views that learning is developing various strategies for recording and obtaining various information, students must actively find the information, and the teacher / educator does not control the stimulus, but becomes the student's partner in the process of finding various information and meanings from the information he obtained in the lessons they discussed and reviewed together [6].

The flow of constructivism developed from cognitive psychology emphasizes his theory that students are very instrumental in discovering new knowledge. Constructivism is a flow that develops a view of learning that emphasizes four key components, namely:

a. Students build their own understanding of the results of their learning not because it is conveyed to them.

b. New lessons are very dependent on previous lessons.

c. Learning can be enhanced by social interaction.

d. Assignments in learning can increase the meaningfulness of the learning process [6].

Even though they have a slight difference, learning theories based on humanistic theory still mean learning as a student-centered process, the teacher / educator has the task of helping instead of directing as in the theory of cognitive psychology learning. It's just that the flow of cognitive psychology further adds to the function of the teacher / educator as a guide for students in learning to explore and experiment [4].

Regarding the role of the teacher or educator, in many places in schools in America, the teacher / educator conducts curriculum transactions with their students, ie the teacher / educator offers a variety of competencies to students, and students choose and determine for themselves what they will learn with his teacher. The implication of the transaction, is the study of students among their fellow students to determine various subject matter materials that they will learn in one particular period. This is what Aldridge calls curriculum as transaction and curriculum as inquiry [9]. 


\section{Orientation to Students}

Humanization, even though it is a concrete historical fact, is not a destiny coming down from heaven, but the result of an unfair order that breeds violence from the hands of the oppressors, who in turn dehumanizes the oppressed [8]. The phrase Freire above emphasizes the main pedagogical differences between Conscientizacao and other forms of education. Conscientizacao is not a technique for information transfer, or even for skills training, but it is a dialogical process that brings individuals together to solve their existential problems. Conscientizacao has the task of liberation, and liberation means the creation of new norms, rules, procedures and policies. Liberation means the transformation of a system of interrelated and complex reality, and changes in some individuals to reduce the negative consequences of their behavior. The main pedagogical differences between Conscientizacao and other forms of education are that the questions raised in Conscientizacao do not have answers that have been previously known. Education is not the organization of facts that are already known in such a way that fools see it as something new. Education not only teaches material to students, but is a search for cooperative answers to the unresolved problems faced by a group of people. Each individual has the same truth, but different in terms of how to see the issues that must be defined and how to find answers that must be formulated. Participation is not an appropriate educational tool, but it is the core of the education process.

Based on Freire's thoughts about Conscientizacao and liberating education for the oppressed, it is appropriate to position students in the capacity of individuals who have the freedom to express themselves, develop their creative potential, and develop their intellectual capacity. Students must be placed as the center (center) of educational and learning activities. Teachers / educators are facilitators, mentors who become students' partners in learning activities. That is the pedagogic of liberation [7], is a pedagogic that empowers students in order to build a new society, namely civil society.

In this context, education means a process of humanization, therefore human rights need to be respected. Students are not robots but humans who must be assisted in the process of maturity so that he can be independent and think critically. In connection with that, the education and learning process must be directed so that the potential that exists in students can be developed as optimally as possible in accordance with their nature, students can contribute their abilities for self-development, community development, and so on for their country, and the life of humanity in general. In the process of empowering students, of course, various prerequisites and infrastructure are needed in implementing it. The main thing is, of course the student's living environment must provide opportunities for developing their potential. The environment should provide opportunities for the development of students so that he is not confined or limited in a goal that has been engineered. Give students the opportunity to develop in accordance with their potential. Thus not only the environment which is an educational resource that must be enriched, but also the management and implementers of the educational process must be in accordance with the demands of independence and human rights that exist in students. Such an education system is an education system directed at empowering students. Empowerment must be part of the culture of the community so that the environment conditions the formation of productive attitudes from students.

The liberation pedagogic that has developed lately is nothing but an educational process that empowers students, the community, and the state, to provide the widest opportunity for individuals who are free from all types of oppressive, both economic, political, and psychological oppression. In essence, according to [8] the basic vision or general goal of the education and learning process in essence is to accompany humans as early as possible to gradually humanize themselves to become mature and independent, and then foster 
interdependent relationships, in the process of actualizing all of its potential to become fully human. The views about the position of students in the learning process are also reinforced by learning theories that many criticize the theory of behaviorism which is accused of killing students' creativity. For example, humanistic learning theory views that the form of learning management is centered on students in the sense that students are free to choose, the teacher or educator only functions as a helper rather than a guide. Likewise, his views on participation, according to this flow, active participation of students takes precedence and children learn by working.

\section{Conclusion}

The existence of collective awareness to lead education towards a better direction in Bilah Regency, has given birth to many new ideas, one of which is the thought of the need for a new orientation in education. At least in the author's perspective, the orientation in question is the need to change the pedagogical paradigm from the classical and narrow to the critical pedagogic. Critical pedagogic is an engineering of thought that seeks to perfect pedagogic which we have known as pedagogic in a narrow paradigm, namely pedagogic that tends to see educational problems merely as technical problems in the classroom. Though education is not merely learning, but education is also closely related to all aspects of human life in society.

Education is not just about making students good at memorizing, but more important is making it as a human being, education is a process of humanizing humans. Education is the process of hominization and the process of humanization of a person in family life, the present and future civilized society. Therefore, even this paradigm shift has implications for the need to reposition educators and students in the education and learning process.

\section{References}

[1] Adiwikarta, S. (1988), Sosiologi Pendidikan: Isyu Hipotesis TentangHubungan Pendidikan dengan Masyarakat. Jakarta: Departemen P dan K.

[2] Harefa, A. (2004), Menjadi Manusia Pembelajar. JurnalPendidikan Luar Sekolah, 3(1),

[3] Nasution, S. (1995), Sosiologi Pendidikan. Jakarta: Bumi Aksara.

[4] Rosyada, D. (2004), Paradigma Pendidikan Demokratis: Sebuah ModelPelibatan Masyarakat dalam Penyelenggaraan Pendidikan. Jakarta: Kencana.

[5] Slavin, RE. (1995), Cooperative Learning: Theory, Research, And Practice. .New York.

[6] Allen and Bacon, Smith, WA. (2001), Conscientizacao: Tujuan Pendidikan Paulo Freire.Yogjakarta: Pustaka Pelajar.

[7] Tilaar, HAR. (2000), Paradigma Baru Pendidikan Nasional.Jakarta:Rineka Cipta.

[8] Tilaar, HAR. (2000), Membenahi Pendidikan Nasional.Jakarta: RinekaCipta.

[9] Wiles, J and Joseph Bondi, (1989), Curriculum Development; a Guide to Practice. Colombo, Toronto, London, Melbourne: Merrill Publishing Company.

[10] William F. O’neil, (2002), Ideologi-ideologi Pendidikan, Yogyakarta: Pustaka Pelajar. 